\title{
Vascular epiphyte biomass in a South Brazilian fragment of Atlantic Forest
}

\author{
MARISE P. PETEAN ${ }^{1}$, AMANDA K. MARCON ${ }^{2}$, DIETER LIEBSCH ${ }^{2}$, \\ FRANKLIN GALVÃO ${ }^{3}$ and RODRIGO A. KERSTEN ${ }^{4}$ \\ ${ }^{1}$ Sociedade Chauá, Rua João Gava, 672, Abranches, 82130-010 Curitiba, PR, Brazil \\ ${ }^{2}$ Programa de Pós-Graduação em Engenharia Florestal, Universidade Federal do Paraná, Avenida \\ Pref. Lothário Meissner, 632, Jardim Botânico, 80210-170 Curitiba, PR, Brazil \\ ${ }^{3}$ Universidade Federal do Paraná, Departamento de Ciências Florestais, Avenida Pref. \\ Lothário Meissner, 632, Jardim Botânico, 80210-170 Curitiba, PR, Brazil \\ ${ }^{4}$ Pontifícia Universidade Católica do Paraná, Centro de Ciências Biológicas e da Saúde, Rua \\ Imaculada Conceição, 1155, Prado Velho, 80215-901 Curitiba, PR, Brazil
}

Manuscript received on January 30, 2018; accepted for publication on June 8, 2018

\begin{abstract}
The present study aimed at sampling the biomass of vascular epiphytes within a protected area in South Brazilian Atlantic Forest. All tree specimens with diameter at breast height equal or greater than $4.8 \mathrm{~cm}$ were measured and divided into classes. In each class, $10 \%$ of tree specimens were randomly selected for epiphytic biomass measuring. Furthermore, we divided the phorophytes into five tree parts to analyze epiphytic biomass. We generated mathematical models to estimate epiphytic biomass in similar forest areas. We analyzed 55 phorophytes and found an estimated epiphytic biomass of $5.3 \mathrm{Mg} / \mathrm{ha}$. Epiphytic biomass ranged from 0.02 to $135 \mathrm{~kg}$ and the lower values were found on small-sized phorophytes. Higher values of epiphytic biomass were found on phorophytes with diameter at breast height between 30 and 36.5 $\mathrm{cm}$. The tree part with higher epiphytic biomass was the outer crown. The epiphytic biomass showed a high correlation with phorophyte diameter, according to the mathematical models. We selected two equations which presented the most similar values to the ones we measured. Our results corroborate that epiphytes play a very important role as to the biomass level within tropical forests.
\end{abstract}

Key words: biomass estimation, carbon storage, crown humus, dead organic matter, epiphytes, epiphytic biomass.

\section{INTRODUCTION}

The Atlantic Forest is the second largest moist tropical forest in the Americas. Ninety-two percent of its area is found within the Brazilian territory (Fundação SOS Mata Atlântica and INPE 2002, Galindo-Leal and Câmara 2003). Epiphyte taxa

Correspondence to: Amanda Koche Marcon

E-mail: amandakoche@gmail.com comprise a significant component in this forest due to both their high diversity and the high amount of biomass that they accumulate (Benzing 1990, Nieder et al. 2001). In moist tropical forests, epiphytes can contribute significantly to species diversity and biomass (40 to 60\%) (Kelly et al. 1994, Ataroff 2001, Kersten and Silva 2006).

Despite epiphytes rarely exceed $2 \%$ of forest dry matter (Nadkarni 1984), their photosynthetic 
biomass, photosynthetic rate and ionic uptake can be equal or even higher than their hosts (Nadkarni 1984, Benzing 1990, Hofstede et al. 1993, Coxson and Nadkarni 1995). As a matter of fact, in some forests, epiphytes can account for $63 \%$ of the photosynthetic biomass (Walker and Ataroff 2002) and nearly $45 \%$ of the mineral content (Nadkarni 1984).

Moreover, epiphytes can absorb and accumulate large amounts of decayed organic matter, which acts as a nutrient source for arboreal fauna and above ground vegetation. They also influence the water dynamics as well as the canopy microclimate (Pócs 1980, Lang et al. 1980, Nadkarni 1984, Hofstede et al. 1993, Bohlman et al. 1995, Freiberg 1996, Freiberg and Freiberg 2000).

Therefore, epiphytes play a very important role as to primary productivity and nutrient cycling in ecosystems. They have the ability to produce substantial amounts of biomass, absorbing and storaging water, retaining nutrients directly from the rain, mist or dust (Nadkarni 1984, Díaz et al. 2010), by rapidly uptaking and restoring energy and ions to the ecosystem (Matelson et al. 1993).

Despite the important role of epiphytes to the maintenance of biological diversity and dynamics within tropical forests, research studies about their contribution as to biomass in these environments are scarce. Among these studies we can highlight Nadkarni (1984) and Ingram and Nadkarni (1993).

To our knowledge, there have been no similar studies in Brazil. Therefore, the present study aimed at quantifying epiphytic biomass within a South Brazilian fragment of Atlantic Forest and answer the following questions: (i) How much do vascular epiphytes contribute to the biomass in a South Brazilian Fragment of Atlantic Forest? (ii) How is epiphytic biomass distributed according to tree-size (defined by diameter classes)? (iii) How is epiphytic biomass distributed along a vertical forest gradient (defined by phorophyte zones)?

\section{MATERIALS AND METHODS}

\section{STUDY AREA}

The survey was carried out at Reserva das Águas, which is found within a protected area of 3300 hectares (Guaraqueçaba Environmental Protection Area) in the State of Paraná, Southern Brazil (Fig. 1). Geographical coordinates are $25^{\circ} 20^{\prime}-25^{\circ} 30^{\prime \prime} \mathrm{S}$ and $48^{\circ} 40^{\prime}-48^{\circ} 50^{\prime \prime} \mathrm{W}$ and altitude varies between 20 and 50 m.a.s.1.

The climate is Cfa (humid subtropical with hot summers), according to Köppen's climate classification (Caviglione et al. 2000), with neither dry season nor frosts (Maack 1968). Total annual precipitation is above $2000 \mathrm{~mm}$, with predominant rainfalls throughout the summer (Vanhoni and Mendonça 2008). The annual mean relative humidity is $85 \%$, and the average annual temperatures are between 19 and $21^{\circ} \mathrm{C}$ (Caviglione et al. 2000, Vanhoni and Mendonça 2008).

Local geology is dominated by very old and eroded rocks (Early Proterozoic), called Cachoeira sequence (Silva et al. 1981). However, the hilltops of the relief are composed mostly of iron quartzites, and therefore, they are more resistant to erosion than the surrounding terrain.

Dominant type of soil is Dystrophic Haplic Cambisol with weak to moderate " $\mathrm{A}$ " horizon and argillaceous texture (F.G. Galvão, personal observation) and the topography is strongly undulating, with slopes between 20 and 30\%. According to the Brazilian Institute of Geography and Statistics (IBGE 2012), vegetation belongs to Atlantic Forest Biome and it is classified as Submontane Dense Ombrophilous Forest.

\section{DATA COLLECTION}

We set out a forest fragment of 1 ha in order to estimate the biomass of vascular epiphytes. This forest is in a medium stage of tree regeneration, containing tree specimens who had their diameter 


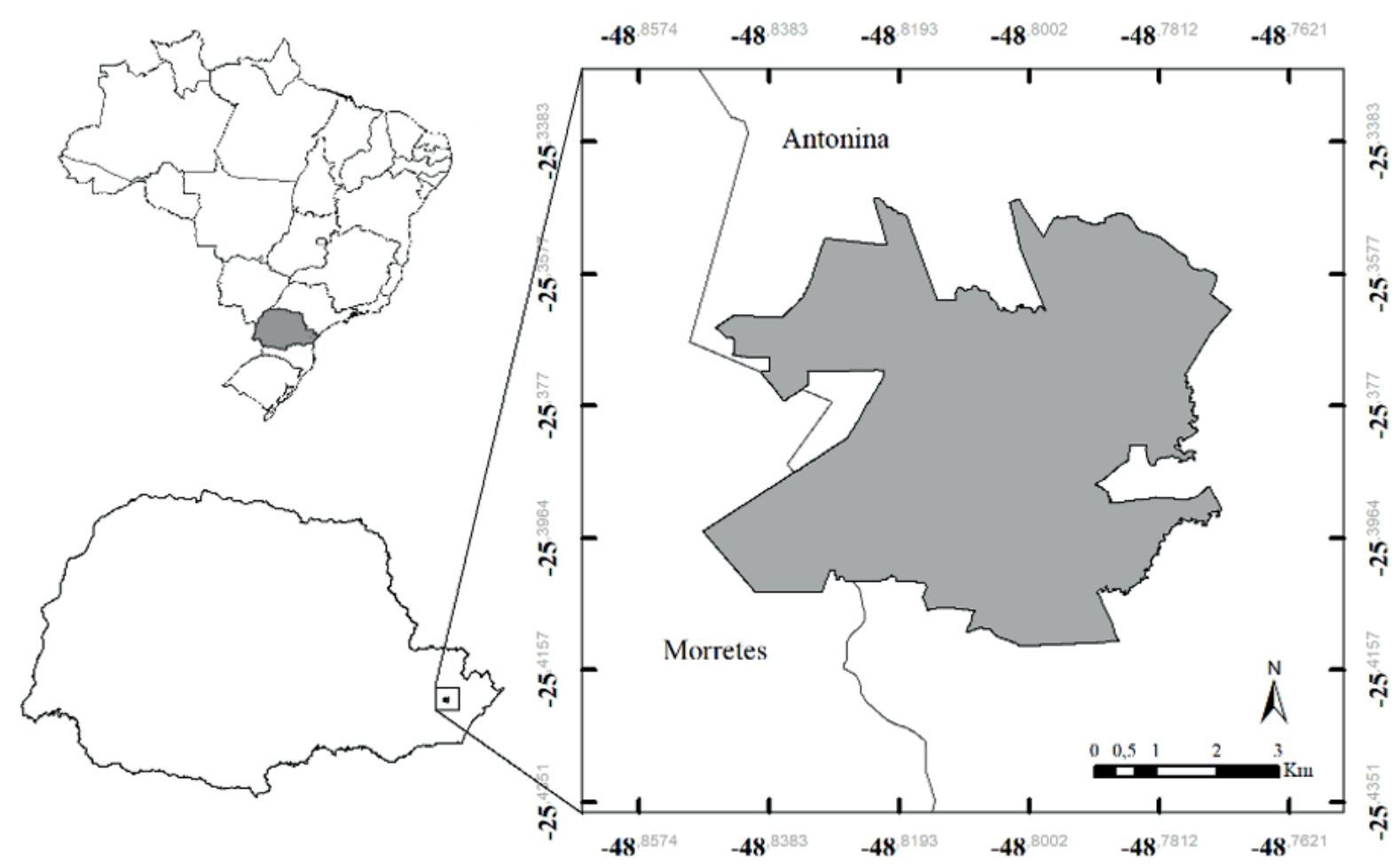

Figure 1 - Localization of study area in the State of Paraná, Southern Brazil.

at breast height $(\mathrm{DBH})$ classified in nine classes. All tree species with DBH equal or greater than 4.8 $\mathrm{cm}$ were numbered with small aluminum plates, so that we could select a representative number of phorophytes belonging to each diameter class (Table I). The term phorophytes were defined here as host trees of an epiphyte (Tremblay and Ackerman 2001). In each class, $10 \%$ of tree specimens were randomly selected, of which we established a maximum of 10 and a minimum of four woody species per diameter class (Table I), in order to sample vascular epiphytes.

We divided the phorophytes into five tree parts in order to assess the epiphytic biomass, based upon the method suggested by Kersten and Waechter (2011a) as follows: (i) lower trunk - it was defined as the portion between its base and 1.3 $\mathrm{m}$ high from the soil surface; (ii) medium trunk the portion between the lower trunk and the upper trunk; (iii) upper trunk - the portion between the first ramification and $1.3 \mathrm{~m}$ below it; (iv) inner crown the portion between the first ramification up to the end of the branches formed from the first ramification; (v) outer crown - the portion which includes all branches formed from the second ramification (Fig. 2).

We used a 7-m aluminum ladder and/or climbing equipment to access epiphytes and manually collect them. In cases where branches had smaller diameter, not supporting a person's weight, these were suppressed. All vascular epiphytes were separated by species and weighed in situ with aid of precision weighing scales $(0.1,1$ and $50 \mathrm{~kg})$. The structural water content of epiphytes was determined by removing a known weight sample of each specie on a tree part. Samples were dried to constant weight in a forced circulation oven at $60{ }^{\circ} \mathrm{C}$.

\section{ANALYSIS}

Data normality were tested by Shapiro-Wilk Test. Results were compared by One-Way ANOVA 
(Analysis of Variance) and effects were further tested using an F-test (Zar 2009).

We built regression models based on the relationship between phorophyte diameter and epiphytic biomass by associating both variables with the highest possible accuracy, aiming to create mathematical models capable of estimating epiphytic biomass in similar Submontane Dense Ombrophilous Forests within the region. We used Student t-test to assess significant differences between the actual values (obtained throughout the sampling) and estimated values (obtained by the equations).

Statistical analysis were carried out using Microsoft Office Excel 365 as well as performed by CurveExpert (version 1.4, by Daniel Hyams).

\section{RESULTS}

We sampled 1 megagram $(\mathrm{Mg})$ of vascular epiphytic biomass (dry weight) corresponding to $5.3 \mathrm{Mg}^{-h^{-1}}$.

Epiphytic dry biomass found on individual phorophytes ranged from $0.02 \mathrm{~kg}$ (sampled on a $12.7 \mathrm{~cm} \mathrm{DBH}$ phorophyte) to $135 \mathrm{~kg}$ (sampled on a $79 \mathrm{~cm} \mathrm{DBH}$ phorophyte - Table II). The lowest

TABLE I

Phorophyte diameter classes, number of trees sampled (TS) and number of randomly selected trees for vascular epiphyte sampling (n).

\begin{tabular}{cccc}
\hline Class & DBH (cm) & TS.ha $^{-1}$ & n \\
\hline I & $4.8-11$ & 1099 & 10 \\
II & $11-17.5$ & 295 & 10 \\
III & $17.5-24$ & 113 & 10 \\
IV & $24-30$ & 59 & 5 \\
V & $30-36.5$ & 48 & 4 \\
VI & $36.5-43$ & 20 & 4 \\
VII & $43-49$ & 15 & 4 \\
VIII & $49-55.7$ & 5 & 4 \\
IX & $\geq 55.7$ & 6 & 4 \\
Total & & 1660 & 55 \\
\hline
\end{tabular}

values of biomass were found on the phorophytes with smaller diameter classes $\left(\mathrm{F}_{8 ; 55}=23.23 ; \mathrm{p}<\right.$ 0.0000).

Distribution of epiphytic biomass within the forest structure showed highest percentage in intermediate diameter class $(30-36.5 \mathrm{~cm})$ (Fig. 3 ). Concerning to biomass distribution along the host tree parts (phorophytes), outer crown showed higher epiphytic biomass than all other parts $\left(\mathrm{F}_{4: 260}\right.$ $=11.17 ; \mathrm{p}<0.0000)$, even when they are added together (Fig. 4). Biomass partitioned in diameter classes demonstrate higher values on trunk only in classes I and II. In all others, outer crown presented greater amounts of biomass (Fig. 5).

Epiphytic biomass had a high positive correlation with phorophyte DBH $(\mathrm{R}=0.935$, $\mathrm{p}$ $\leq 0.05)$. Among all mathematical equations tested to determine epiphytic biomass, two of them had estimated values closest to the measured data (Fig. 6). Linear regression (equation a) is more accurate to estimate the biomass of large tree specimens $(\mathrm{R}=0.876, \mathrm{p} \leq 0.05)$, but it could result in underestimated and even negative values for small woody specimens (DBH lower than 14

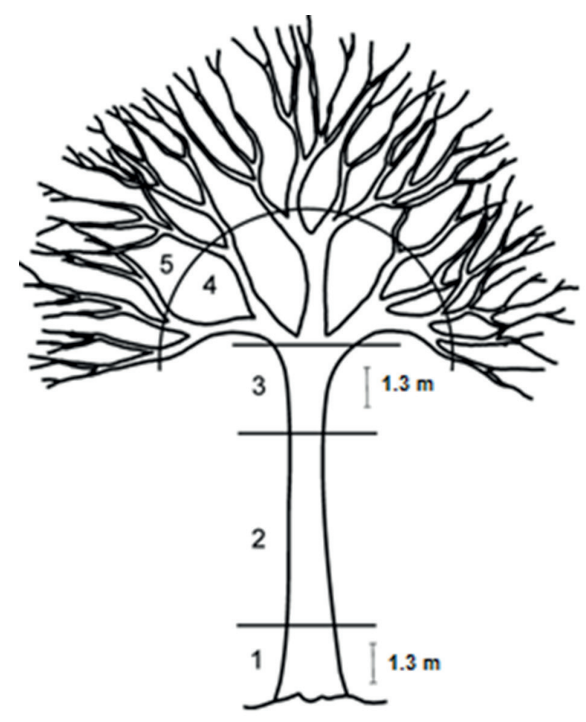

Figure 2 - Tree (phorophyte) parts: 1 - lower trunk; 2 medium trunk; 3 - upper trunk; 4 - inner crown; 5 - outer crown (based on Kersten and Waechter 2011a). 
TABLE II

Dry and wet epiphytic biomass minimum (min), medium (med) and maximum (max) on the phorophytes in each diameter class.

\begin{tabular}{|c|c|c|c|c|c|c|}
\hline \multirow{2}{*}{$\begin{array}{l}\text { DBH } \\
\text { Class }\end{array}$} & \multicolumn{3}{|c|}{ Dry biomass (kg) } & \multicolumn{3}{|c|}{ Wet biomass (kg) } \\
\hline & $\min$ & med & $\max$ & $\min$ & med & $\max$ \\
\hline I & 0.03 & 0.6 & 2.4 & 0.2 & 2.9 & 12.1 \\
\hline II & 0.02 & 1.0 & 2.9 & 0.1 & 5.0 & 13.5 \\
\hline III & 0.06 & 1.9 & 5.1 & 0.4 & 10.9 & 29.1 \\
\hline IV & 2.6 & 11.6 & 17.2 & 18.8 & 57.5 & 88.5 \\
\hline V & 16.0 & 30.6 & 56.0 & 92.3 & 169.6 & 298.5 \\
\hline VI & 17.6 & 22.6 & 27.7 & 75.1 & 95.8 & 114.9 \\
\hline VII & 40.2 & 56.3 & 78.1 & 191.1 & 252.1 & 312.0 \\
\hline VIII & 29.2 & 45.4 & 66.7 & 145.1 & 211.6 & 306.4 \\
\hline IX & 30.4 & 87.0 & 135.6 & 170.8 & 456.2 & 701.4 \\
\hline
\end{tabular}

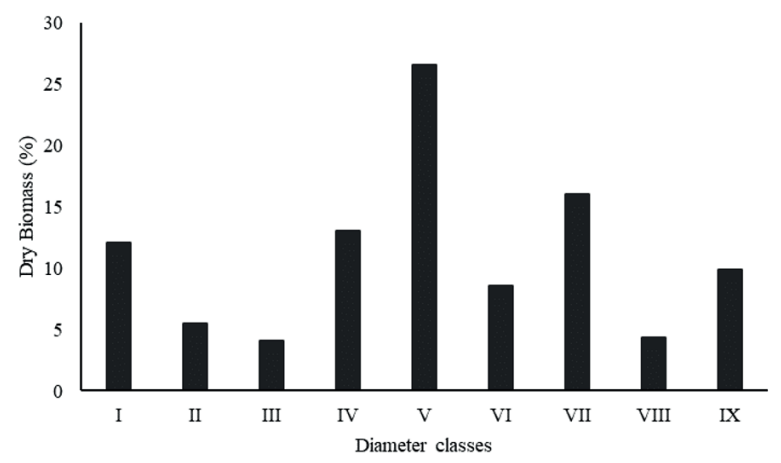

Figure 3 - Vascular epiphyte dry biomass per diameter classes in a South Brazilian fragment of Atlantic Forest.

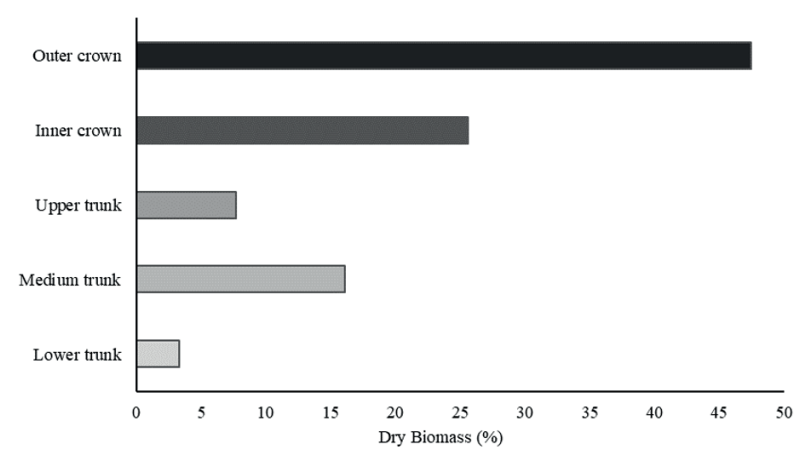

Figure 4 - Vascular epiphyte dry biomass per tree parts in a South Brazilian fragment of Atlantic Forest. $\mathrm{cm})$. Non-linear Regression (equation "b") seems to be best suited for estimating epiphytic biomass in shorter tree individuals $(\mathrm{R}=0.889, \mathrm{p} \leq 0.05)$, but it underestimates the biomass in large tree individuals. It should be noted that both equations exhibited $\mathrm{R}$ values greater than 0.8 (Fig. 6).

Student t-test has not shown significant differences between measured biomass values and estimated biomass values (Linear: $p=0.97$; Nonlinear: $\mathrm{p}=0.96$ ).

\section{DISCUSSION}

Research studies exclusively quantifying the amount of epiphytic biomass are scarce, and they mostly focus on the avascular epiphytic component found in the Neotropical montane regions of the Northern Hemisphere (Table III).

The overall epiphytic biomass within the Submontane Dense Ombrophilous Forest of Reserva das Águas, can be considered high when compared to other tropical and subtropical forests (Table III). It is noteworthy that studies which specifically encompass epiphytic biomass are nonexistent in Brazil, although some survey studies quantified total forest biomass and also included epiphytic biomass. In one of these studies carried out in the Alluvial Mixed Ombrophilous Forest, Socher et al. (2008) quantified vascular epiphytic biomass as $0.47 \mathrm{Mg} \cdot \mathrm{ha}^{-1}$, which corresponds to $10 \%$ of the overall epiphytic biomass found within Reserva das Águas. Although the low number of epiphytes indicates significant environmental changes in the region due to anthropic impacts (Castela and Britez 2004), vascular epiphytism in Mixed Ombrophilous Forests is less abundant and less diverse than in Dense Ombrophilous Forests (Kersten et al. 2009, Kersten 2010).

Some studies reported smaller amounts of epiphytic biomass than those found within Reserva das Águas. Methodological aspects may have caused these differences. Nadkarni (1984) 


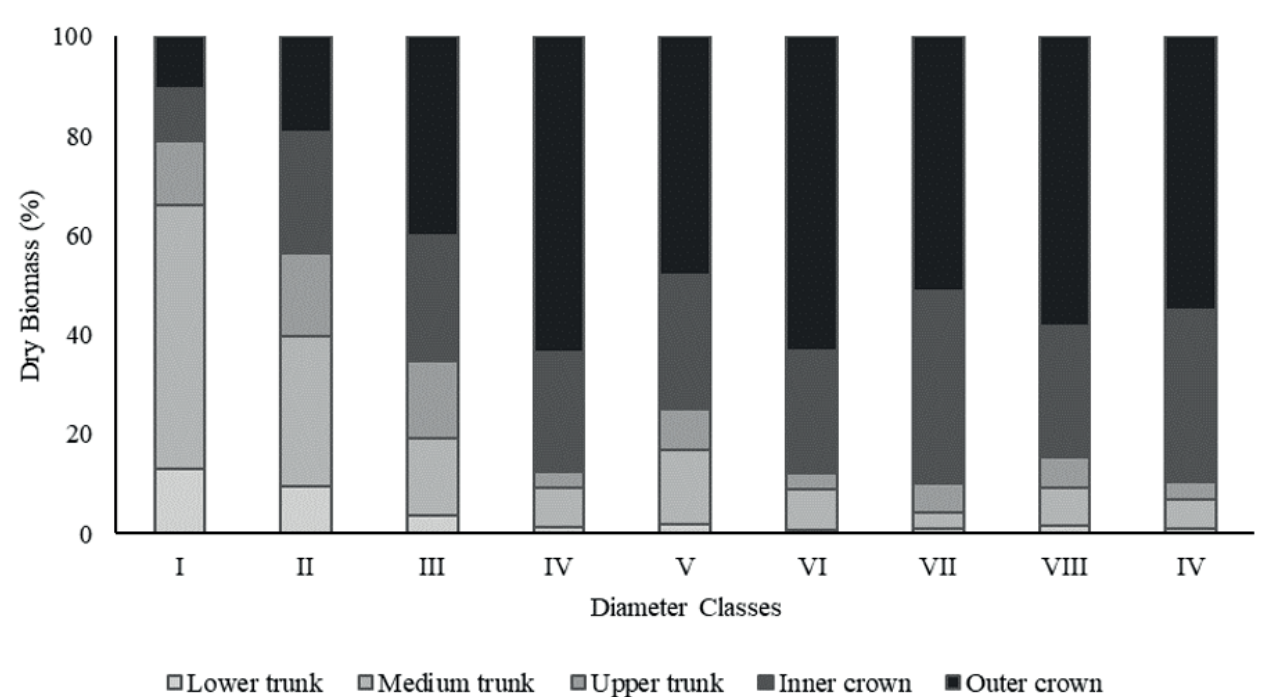

Figure 5 - Vascular epiphyte dry biomass per diameter classes and tree parts in a South Brazilian fragment of Atlantic Forest.

evaluated epiphytic biomass contained in only one dominant species, while Caballero-Rueda et al. (1997) developed the study in a regenerating forest.

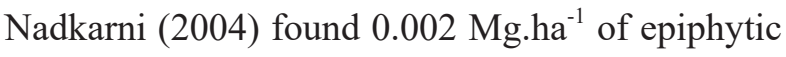
biomass in a secondary forest, old pasture, also composed mainly of one species. Similarly, Köhler et al. (2007) measured $0.08 \mathrm{Mg} \cdot \mathrm{ha}^{-1}$ in a 30 years old secondary forest.One of the biggest obstacles to study epiphytes is the difficulty in accessing the forest canopy (Moffett and Lowman 1995, Mitchell et al. 2002), causing restrictions to the number of tree samplings (Freiberg 1996, Freiberg and Freiberg 2000). Throughout this study, there has been a great sampling effort, representing a total of 55 tree specimens measured through destructive sampling of the epiphytes, which resulted in a more accurate data collection when compared to other studies carried out with a limited number of samples or even using a single phorophyte. Our sampling method is likely to have contributed to the high amount of estimated biomass, since we sampled phorophytes of several species, distributed in a wide range of diameters, without neglecting the full range of epiphytic biomass found in small and medium-sized trees.
In the Neotropical region some studies (Nadkarni et al. 2004, Walker and Ataroff 2002, Werner et al. 2011) reported vascular epiphytic biomass amounts higher than the values found within Reserva das Águas. In these cases, the studies were carried out in primary or old-growth forests, whereas Reserva das Águas basically comprises secondary forests. Moreover, both diversity and abundance of epiphytes are substantially low in disturbed environments, especially within secondary forests in comparison to primary or oldgrowth forests (Whitmore 1990, Hietz et al. 1996).

The high biomass values reported by Nadkarni et al. (2004) can be related to the forest structure, which has a 15-30 m high canopy and a high abundance of large-diameter tree species, accounting for more than 150 specimens per hectare. These characteristics differ from the Reserva das Águas structure, in which tree canopies are rarely more than $15 \mathrm{~m}$ of height and comprise less than 100 large woody specimens per hectare. The forest studied in Costa Rica is located in a region of low to intermediate altitudes, which in a large-scale can be considered as a more representative and suitable environment for vascular epiphytism (Nieder et al. 1999, Küper et al. 2004, Krömer et al.2005). 
TABLE III

Studies on the epiphytic biomass performed in Dense Ombrophilous Forests in the Americas. Latitude (Lat.), longitude (Lon.), altitude (Alt.), vegetation typology (Type**), vascular epiphytic biomass (VEB). SMF = submontane forest; MF = montane forest; HMF = high montane forest; SF = secondary forest; OGF = old growth forest; - = uninformed.

\begin{tabular}{cccccccc}
\hline Country & Lat. & Lon. & $\begin{array}{c}\text { Alt. } \\
\text { (m.a.s.l.) }\end{array}$ & Type** & $\begin{array}{c}\text { Successional } \\
\text { stages }\end{array}$ & $\begin{array}{c}\text { VEB } \\
\text { (Mg.ha } \text { (1) }^{-1}\end{array}$ & Reference \\
\hline Venezuela & $8 \mathrm{~N}$ & $70 \mathrm{~W}$ & 2400 & HMF & - & $9.9^{*}$ & Walker and Ataroff (2002) \\
Colombia & $4 \mathrm{~N}$ & $74 \mathrm{~W}$ & 2700 & HMF & SF & $2.4^{*}$ & Caballero-Rueda et al. (1997) \\
Colombia & $5 \mathrm{~N}$ & $75 \mathrm{~W}$ & 3700 & HMF & SF & 4.8 & Hofstede et al. (1993) \\
Panama & $9 \mathrm{~N}$ & $78 \mathrm{~W}$ & 500 & SMF & - & 1.4 & Golley et al. (1971) \\
Costa Rica & $10 \mathrm{~N}$ & $84 \mathrm{~W}$ & 1500 & MF & - & 4.7 & Nadkarni (1984) \\
Costa Rica & $10 \mathrm{~N}$ & $84 \mathrm{~W}$ & 1480 & MF & OGF & 8.2 & Nadkarni et al. (2004) \\
Costa Rica & $10 \mathrm{~N}$ & $84 \mathrm{~W}$ & 14800 & MF & SF & 0.002 & Nadkarni et al. (2004) \\
Costa Rica & $10 \mathrm{~N}$ & $84 \mathrm{~W}$ & 1490 & MF & OGF & 2.6 & Köhler et al. (2007) \\
Costa Rica & $10 \mathrm{~N}$ & $84 \mathrm{~W}$ & 1620 & MF & SF (30 years) & 0.08 & Köhler et al. (2007) \\
Ecuador & $4 \mathrm{~S}$ & $79 \mathrm{~W}$ & 2500 & HMF & OGF & $10.1 *$ & Werner et al. (2011) \\
Brazil & $25 \mathrm{~S}$ & $48 \mathrm{~W}$ & 200 & SMF & SF & $5.3 *$ & Present study \\
\hline
\end{tabular}

*Only live biomass; **Typology adapted and reclassified according to IBGE (2012), following the data provided by the mentioned authors.
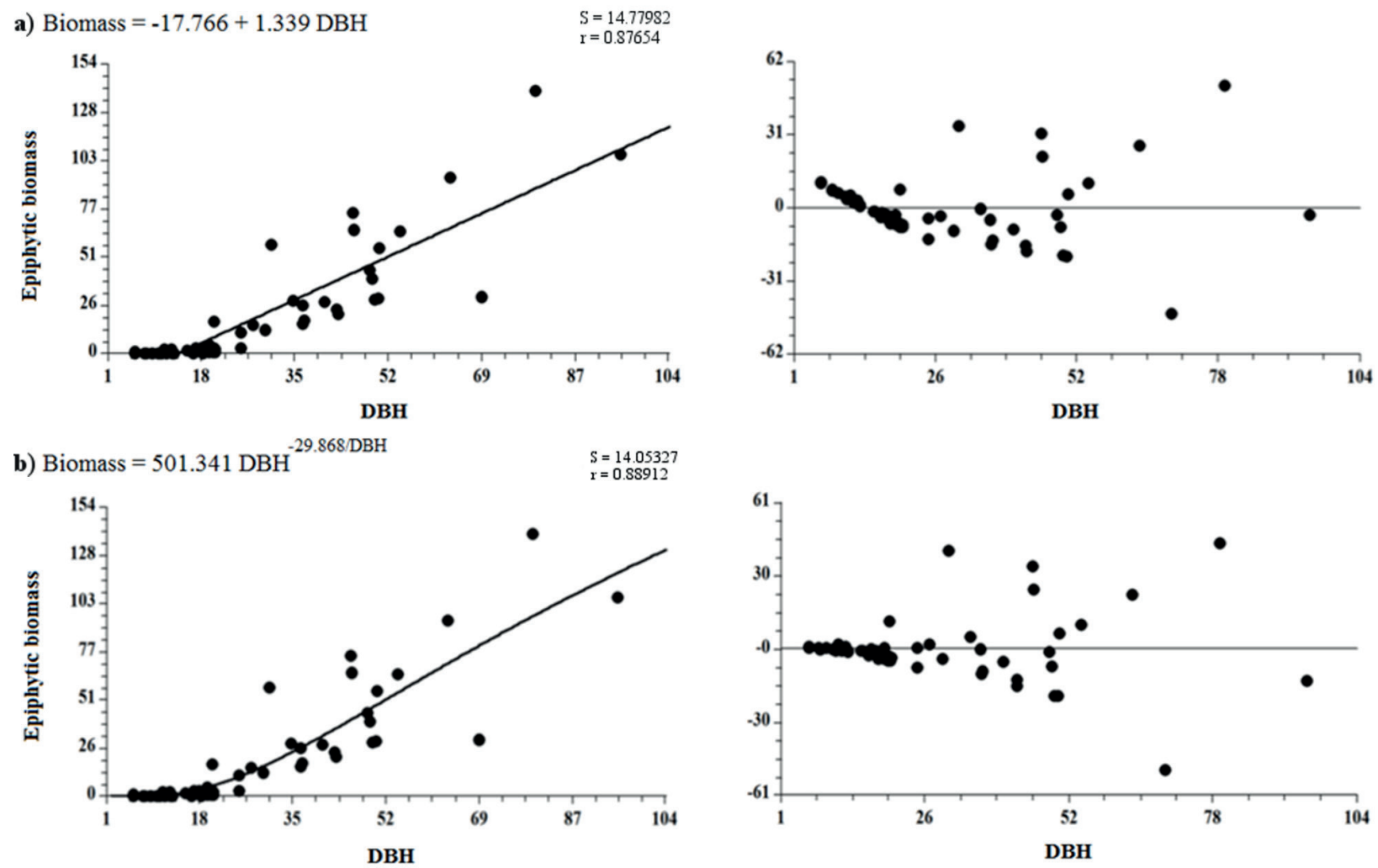

Figure 6 - Mathematical models used to test vascular epiphytic dry biomass estimated from phorophyte DBH and residuals. a) Linear regression; b) Non-linear regression. 
The forest studied by Walker and Ataroff (2002) exhibited a higher canopy, as well as a higher and more constant relative humidity, which is evidenced by increased cloudiness and lower insolation, as described by the authors. These conditions are mostly responsible for epiphyte settlement and growth (Hernández-Rosas 2004, Woda et al. 2006, Köhler et al. 2007).

Nadkarni (1984) asserts that epiphytic composition varies according to the size of phorophytes, rather than variations among different species with similar stem diameter. Although epiphytic biomass is higher on older phorophytes as they are exposed to longer periods of epiphytic colonization (Krömer et al. 2007), whereas young, small tree specimens seem to sustain an important amount of epiphytic biomass due to their high density within the forest structure.

Based upon our findings, $48 \%$ of epiphytic biomass within Reserva das Águas were sampled in trees with DBH between 24 and $43 \mathrm{~cm}$, which can be considered medium-sized. If we consider all individuals with DBH less than $43 \mathrm{~cm}$, small and medium-sized trees account for $70 \%$ of the epiphytic biomass. Similarly, forestry studies performed by Köhler et al. (2007) exhibited high epiphytic biomass values (48\%) on tree specimens of similar diameter range (DBH between 24 and $49 \mathrm{~cm})$.

Phorophyte size has been often related to epiphytic diversity and abundance (Laube and Zotz 2006, Zotz and Schultz 2008, Kersten et al. 2009). Large trees exhibit a more complex spatial structure which provides more microhabitats, substrate for colonization and a larger area for seed deposition (Sáyago et al. 2014). The epiphyte biomass is also correlated with the age of the trees, since older trees have been available for colonization during longer periods of time (Kersten and Waechter 2011a).

Thus, we may infer that, although larger phorophytes tend to harbor more epiphytes, they have lower population density than small and medium-sized phorophytes. Therefore, in this study, the set of medium-sized trees show higher levels of epiphytic colonization, which provide an important support for epiphytic sinusia. Although small-sized trees harbor low levels of epiphytes individually, they play a very important role in the environment dynamics. Zotz (2007) had similar results and concluded that studying only large host trees is likely to result in a biased representation of the epiphyte community.

Research studies about epiphytic flora (including all tree parts) that analyzed biomass stratification were based upon non-constant methods, which make it difficult to make further comparisons among them. According to our findings, the epiphytic biomass distribution within Reserva das Águas was similar to that observed by Nadkarni (1984) as to the crown epiphytic biomass. It has also been reported in several other research studies that epiphytic richness and abundance were higher in the crown rather than on the trunk (Kersten et al. 2009, Kersten and Waechter 2011b, Caglioni et al. 2012, Oliveira et al. 2013).

It is well known that, distribution is not uniform when forest canopies are analyzed. Nadkarni (1984) found higher epiphytic biomass in the inner crown (45\%), while within Reserva das Águas higher biomass was found in the outer crown $(46 \%)$. These differences may be due to different parts of the crown, associated with the fact that Nadkarni (1984) also measured the suspended organic matter (decaying organic matter located on the branches of phorophytes, in association with epiphytes), accumulated in large amounts in the inner crown. Additionally, difficulties in accessing outer crown may cause sub-sampling. In this study, the outermost branches were suppressed - allowing sampling all epiphytic biomass - which could justify our results.

Trunk presented greater abundance of epiphytic biomass in smaller-sized phorophytes, while outer crowns showed greater amounts in 
individuals above $17.5 \mathrm{~cm}$ diameter. Usually, large trees have larger crowns than small trees - most of them exhibiting a significant linear relationship between crown and trunk diameters (Hemery et al. 2005) - providing further hosting area for epiphytes. According to Nadkarni (1984), overall epiphytic biomass ranges between 1.5 and $2.2 \%$ of total forest aerial biomass. These percentages were based on epiphytic biomass proportion from a forest in Costa Rica in relation to the overall aerial biomass (secondary data) from forests in New Guinea, Jamaica and Panama. On the other hand, the epiphytic biomass surveyed within Reserva das Águas corresponds to 3\% of total biomass, similar to what was found by Nadkarni (1984). Our findings are based upon the overall aerial biomass estimated for Reserva das Águas (173.3 Mg.ha ${ }^{-1}$ ), using the equation proposed by Brown and Iverson (1992), which solely accounts for tree specimens.

Live epiphytic tissues vary from 55 to $90 \%$ (Hsu et al. 2002, Nadkarni 1984) of total epiphytic biomass (including decaying organic matter associated to live epiphytes). However, only a fraction of this biomass comprises photosynthetic tissues. Estimates by Hsu et al. (2002), studying an area with a latitude similar to ours, indicated that nearly $70 \%$ of live epiphytic biomass is composed of photosynthetic tissues. Thus, based on such percentage we can estimate that photosynthetic epiphyte biomass within Reserva das Águas corresponds to approximately 3.7 Mg.ha ${ }^{-1}$.

Moreover, one of the very few studies that considered solely tree leaf biomass, in a tropical rainforest (Golley et al. 1978), indicated that leaves correspond to $3.8 \%$ of forest aerial biomass. Based upon this percentage, we can estimate that leaf biomass at Reserva das Águas corresponds to 6.6 $\mathrm{Mg} \cdot \mathrm{ha}^{-1}$, and therefore, epiphytes $(3.7 \mathrm{Mg}$ of the green biomass) account for nearly $36 \%$ of the forest epiphytic biomass.

According to Coxson and Nadkarni (1995), epiphytic leaf biomass, when compared to the phorophytes, can reach $51 \%$ of above-ground photosynthetic biomass. Hence, the estimates for the Reserva das Águas agree with the reported proportions, although they are based on secondary data, which are very close to the values found by Nadkarni (1984) and Hsu et al. (2002) since they reported percentages between 30 and $43 \%$, respectively.

As far as phorophytes are concerned, organic matter associated with the epiphytes influences nutrient cycling, since it provides a rich source of nutrients that becomes available to the aboveground fauna and vegetation (Pike 1977, Nadkarni 1981, Coxson and Nadkarni 1995). In this study, organic matter associated with epiphytes was calculated based on the values reported by Hsu et al. (2002), Nadkarni (1984) and Hofstede et al. (1993). Therefore, we estimate the organic matter to range between 0.5 and $2.4 \mathrm{Mg} \cdot \mathrm{ha}^{-1}$.

Based upon our findings, the high correlation among these parameters allows the estimation of epiphytic biomass as it can be observed in linear regression, or even non-linear mathematical models. The models were not evaluated in other areas for validation because this would imply in another suppression of phorophytes, which is not appropriate considering nature conservation. However, the high correlation and the fact that we had not shown significant differences between measured biomass values and estimated biomass values indicates that the epiphytic biomass found on any phorophyte can be estimated, provided it is located within a similar forest structure.

All in all, the analyzed equations to estimate epiphytic biomass showed measures of precision with similar values, and in all cases the coefficients of determination were higher than 0.85 and the standard errors lower than 15 . The equation that best describes the data is the one that corresponds to the non-linear model, because in addition to presenting the best measures of precision, it also presented a higher coefficient of determination 
and lower standard error, being more efficient when compared to the other non-linear equations, resulting in estimated values more similar to the actual ones.

Simple linear regression was not suitable to estimate epiphytic biomass on phorophytes with DBH smaller than $14 \mathrm{~cm}$, resulting in negative values. The graph of residuals shows that the equation is likely to underestimate epiphytic biomass on small-sized phorophytes. Moreover, we may infer that the non-linear regression is more suitable for the estimates, as it presented a residual distribution pattern, which is satisfactory for phorophytes under all diameter classes.

\section{CONCLUSIONS}

The epiphytic biomass found within Reserva das Águas, even though it is a secondary forest, was quite high in comparison to other forests studied throughout the Neotropical region.

The individual tree size affects epiphytic biomass, which indicates that the maintenance of mature forests is essential to preserve the diversity of vascular epiphytes. Although epiphytic biomass is higher on large-sized trees, young and thin-stemmed trees should not be neglected in quantitative studies. Even if they harbor small epiphytic biomass individually, such tree specimens can support a significant amount of epiphytic component due to their high density. We finally concluded that higher biomass values were found on the outer crown of phorophytes.

\section{REFERENCES}

ATAROFF M. 2001. Venezuela. In: Kappelle M and Brown AD (Eds), Bosques Nublados del Neotrópico, Costa Rica: Editorial IMBIO, p. 397-442.

BENZING DH. 1990. Vascular epiphytes. New York: Cambridge University Press, 354 p.

BOHLMAN SA, MATELSON TJ AND NADKARNI NM. 1995. Moisture and temperature patterns of canopy humus and forest floor soil of a montane cloud forest, Costa Rica. Biotropica 27: 13-19.
BROWN S AND IVERSON LR. 1992. Biomass estimates for tropical forests. World Resources Review 4: 366-384.

CABALLERO-RUEDA LM, NELLY R AND MARTÍN C. 1997. Dinámica de elementos en epífitos de um bosque altoandino de la Cordillera Oriental de Colombia. Caldasia Bogotá 19: 311-322.

CAGLIONI E ET AL. 2012. Epífitos vasculares predominantes em zonas ecológicas de forófitos, Santa Catarina, Brasil. Rev Estud Ambient 14: 28-42.

CASTELA PR AND BRITEZ RM. 2004. A floresta com Araucária no estado do Paraná. Brasília: Ministério do Meio Ambiente.

CAVIGLIONE JH, KIIHL LRB, CARAMORI PH AND OLIVEIRA D. 2000. Cartas climáticas do Estado do Paraná. Londrina: Iapar. Disponível em: $<$ http://www. iapar.br/pagina-677.html>. Acessado em 6 de abril de 2017.

COXSON DS AND NADKARNI NM. 1995. Ecological roles of epiphytes in nutrient cycles. In: Lowman MD and Nadkarni NM. Forest Canopies, San Diego: Academic Press, San Diego, California, USA, p. 73-106.

DÍAZ IA, SIEVING KE, PENA-FOXON ME, LARRAÍN J AND ARMESTO JJ. 2010. Epiphyte diversity and biomass loads of canopy emergent trees in Chilean temperate rain forests: A neglected functional component. For Ecol Manage 259(8): 1490-1501.

FREIBERG M. 1996. Spatial distribution of vascular epiphytes on three emergent canopy trees in French Guiana. Biotropica 28: 345-355.

FREIBERG M AND FREIBERG E. 2000. Epiphyte diversity and biomass in the canopy of lowland and montane forests in Ecuador. J Trop Ecol 16: 673-688.

FUNDAÇÃO SOS MATA ATLÂNTICA AND INPE. 2002. Atlas dos remanescentes florestais da Mata Atlântica e ecossistemas associados no período de 1995-2000. São Paulo: Fundação SOS Mata Atlântica \& INPE, 45 p.

GALINDO-LEAL C AND CÂMARA IG. 2003. Atlantic forest hotspots status: an overview. In: Galindo-Leal C and Câmara IG (Eds), The Atlantic Forest of South America: biodiversity status, threats, and outlook, Washington: Center for Applied Biodiversity Science and Island Press, Washington, D.C., p. 3-11.

GOLLEY FB, MCGINNIS JT AND CLEMENTS RG. 1971. La biomasa y la estructura mineral de algunos bosques de Darién, Panamá. Turrialba 21: 189-196.

GOLLEY FB, MCGINNIS JT, CLEMENTS RG, CHILD GI AND DUEVER MJ. 1978. Ciclagem de minerais em um ecossistema de floresta tropical úmida. EDUSP, São Paulo, $256 \mathrm{p}$.

HEMERY GE, SAVILL PS AND PRYOR SN. 2005. Applications of the crown diameter-stem diameter relationship for different species of broadleaved trees. For Ecol Manag 215: 285-294. 
HERNÁNDEZ-ROSAS JI. 2004. Caracteristicas del substrato de plantas del dosel de un bosque humedo tropical de tierras bajas (Alto Orinoco, venezuela). Acta Cient Venez 55: $35-43$

HIETZ-SEIFERT U, HIETZ P AND GUEVARA S. 1996. Epiphyte vegetation and diversity on remnant trees after forest clearance in southern Veracruz, Mexico. Biol Conserv 75: 103-111.

HOFSTEDE RGM, WOLF JHD AND BENZING DH. 1993. Epiphytic biomass and nutrient status of a Colombian upper montane rain forest. Selbyana 14: 37-45.

HSU CC, HORNG FW AND KUO CM. 2002. Epiphyte biomass and nutrient capital of a moist subtropical forest in north-eastern Taiwan. J Trop Ecol 18: 659-670.

IBGE - INSTITUTO BRASILEIRO DE GEOGRAFIA E ESTATÍSTICA. 2012. Manual técnico da vegetação brasileira. Rio de Janeiro: IBGE, $271 \mathrm{p}$.

INGRAN SW AND NADKARNI NM. 1993. Composition and distribution of epiphytic organic matter in a neotropical cloud forest. Biotropica 25: 370-383.

KELLY DL, TANNER EVJ, NIC LUGHADHA EM AND KAPOS V. 1994. Floristics and biogeography of a rain forest in the Venezuelan Andes. J Biogeogr 21: 421-440.

KERSTEN RA. 2010. Epífitas vasculares - Histórico, participação taxonômica e aspectos relevantes, com ênfase na Mata Atlântica. Hoehnea 37: 9-38.

KERSTEN RA, BORGO M AND SILVA SM. 2009. Diversity and distribution of vascular epiphytes in an insular Brazilian coastal forest. Rev Biol Trop 57: 749-759.

KERSTEN RA AND SILVA SM. 2006. The floristic compositions of vascular epiphytes of a seasonally inundated forest on the coastal plain of Ilha do Mel Island, Brazil. Rev Biol Trop 54: 935-942.

KERSTEN RA AND WAECHTER JL. 2011a. Métodos quantitativos no estudo de comunidades epifíticas. In: Felfili-Fagg JM, Eisenlohr PV, Melo MMRF, Andrade LA and Meira Neto JAA (Eds), Fitossociologia no Brasil: métodos e estudos de caso, Viçosa: Editora UFV, p. 231254.

KERSTEN RA AND WAECHTER JL. 2011b. Florística e Estrutura das epífitas vasculares em zona ecotonal entre as Florestas Ombrófilas Mista e Densa, vertente oeste da Serra do Mar paranaense. In: Felfili-Fagg JM, Eisenlohr PV, Melo MMRF, Andrade LA and Meira Neto JAA (Eds), Fitossociologia no Brasil: métodos e estudos de caso, Viçosa: Editora UFV, p. 479-503.

KÖHLER L, TOBÓN C, FRUMAU KF AND BRUJINZEEL LA. 2007. Biomass and water storage dynamics of epiphytes in old-growth and secondary montane cloud forest stands in Costa Rica. Plant Ecol 193: 171-184.

KRÖMER T, KESSLER M AND GRADSTEIN SR. 2007. Vertical stratification of vascular epiphytes in submontane and montane forest of the Bolivian Andes: the importance of the understory. Plant Ecol 189: 261-278.

KRÖMER T, KESSLER M, GRADSTEIN SR AND ACEBEY A. 2005. Diversity patterns of vascular epiphytes along an elevational gradient in the Andes. J Biogeogr 32: 17991809.

KÜPER W, KREFT H, NIEDER J, KÖSTER N AND BARTHLOTT W. 2004. Large-scale diversity patterns of vascular epiphytes in Neotropical montane rain forests. J Biogeogr 31: 1477-1487.

LANG GE, REINERS WA AND PIKE LH. 1980. Structure and biomass dynamics of epiphytic lichen communities of balsam fir forests in New Hampshire. Ecology 61: 541550 .

LAUBE S AND ZOTZ G. 2006. Neither host-specific nor random: vascular epiphytes on three tree species in a Panamanian lowland forest. Ann Bot 97: 1103-1114.

MAACK R. 1968. Geografia física do Estado do Paraná. Curitiba: Banco do Desenvolvimento do Paraná, 350 p.

MATELSON TJ, NADKARNI NM AND LONGINO JT. 1993. Survivorship of fallen epiphytes in a Neotropical cloud forest, Monteverde, Costa Rica. Ecology 74: 265269.

MITCHELL AW, SECOY K AND JACSON T. 2002. The global canopy handbook. Techniques of access and study in the forest roof. Oxford, UK: Global Canopy Programme, $248 \mathrm{p}$.

MOFFETT MW AND LOWMAN MD. 1995. Canopy access techniques. In: Lowman MD and Nadkarni NM (Eds), Forest Canopies. Academic Press, Inc, 544 p.

NADKARNI N. 1981. Canopy Roots: Convergent Evolution in Rainforest Nutrient Cycles. Science 214: 1023-1024.

NADKARNI N. 1984. Epiphyte Biomass and Nutrient Capital of a Neotropical Elfin forest. Biotropica 16: 249-256.

NADKARNI NM, SCHAEFER D, MATELSON TJ AND SOLANO R. 2004. Biomass and nutrient pools canopy and terrestrial components in a primary and secondary montane cloud forest, Costa Rica. For Ecol Manage 198: 223-236.

NIEDER J, ENGWALD S AND BARTHLOTT W. 1999. Patterns of neotropical epiphyte diversity. Selbyana 20: 66-75.

NIEDER J, PROSPERÍ J AND MICHALOUD J. 2001. Epiphytes and their contribution to canopy diversity. Plant Ecol 153: 51-63.

OLIVEIRA LC, PADILHA PT, DALMOLIN EB, AZEREDO TEV AND CITADINI-ZANETTE V. 2013. Componente epifítico vascular de um fragmento florestal urbano, município de Criciúma, Santa Catarina, Brasil. Biotemas 26: 33-44.

PIKE LH, DENISON WC AND RYDELL RA. 1977. A 400year-old Douglas fir tree and its epiphytes: biomass, 
surface area, and their distributions. Can J For Res 7: 680699.

PÓCS T. 1980. The epiphytic biomass and its effect on the water balance of two rain forest types in the Uluguru Mountains (Tanzania, East Africa). Acta Bot Hung 26: 143-167.

SÁYAGO R, LOPEZARAIZA-MIKEL M, QUESADA M, ÁLVAREZ-AÑORVE MY, CASCANTE-MARÍN A AND BASTIDA JM. 2013. Evaluating factors that predict the structure of a commensalistic epiphyte-phorophyte network. Proc Biol Sci 280: 20122821.

SILVA ATSF, FRANCISCONI O, GODOY AM AND BATOLLA JUNIOR F. 1981. Projeto Integração e Detalhe Geológico no Vale do Ribeira. Relatório Final: Integração Geológica, v. 1. São Paulo: Superintendência Regional de São Paulo, 264 p.

SOCHER LG, RODERJAN CV AND GALVÃO F. 2008. Biomassa aérea de uma floresta ombrófila mista aluvial no município de Araucária (PR). Floresta 38: 245-252.

TREMBLAY RL AND ACKERMAN JD. 2001. Gene flow and effective population size in Lepanthes (Orchidaceae): a case for genetic drift. Biol J Linn Soc 72: 47-62.
VANHONI F AND MENDONÇA F. 2008. O clima do litoral do estado do Paraná. Rev Bras Climatologia 3: 49-63.

WALKER R AND ATAROFF M. 2002. Biomasa epifita y su contenido de nutrientes en una selva nublada andina, Venezuela. Ecotropicos 15: 203-210.

WERNER FA, HOMEIER J, OESKER M AND BOY J. 2011. Epiphytic biomass of a tropical montane forest varies with topography. J Trop Ecol 28: 23-31.

WHITMORE TC. 1990. An introduction to the tropical rain forests. Oxford: Clarendon Press, 226 p.

WODA C, HUBER A AND DOHRENBUSCH A. 2006. Vegetación epifita y captación de neblina en bosques siempreverdes en la Cordillera Pelada, sur de Chile. Bosque 27: 231-240.

ZAR HJ. 2009. Biostatistical Analysis. $5^{\text {th }}$ ed., Pearson: New Jersey, $960 \mathrm{p}$.

ZOTZ G. 2007. Johansson revisited: the spatial structure of epiphyte assemblages. J Veg Sci 18(1): 123-130.

ZOTZ G AND SCHULTZ S. 2008. The vascular epiphytes of a lowland forest in Panama-species composition and spatial structure. Plant Ecol 195: 131-141. 